\title{
PENGARUH KUALITAS PRODUK DAN BRAND IMAGE HANDPHONE SAMSUNG TERHADAP PURCHASE INTENTION KONSUMEN PADA GALERI TEKNOLOGI DI BADUNG
}

\author{
Ni Ketut Budiani, Ni Wayan Ari Sudiartini , A.A Elik Astari,dan I Dewa \\ Nyoman Usadha \\ Fakultas Ekonomi, Universitas Mahendradatta, J1. Ken Arok No.12, Peguyangan, \\ Denpasar Utara, Kota Denpasar, Bali 80115 \\ Telp/Fax :(0361) 434827/0361-249471, \\ Email : info@mahendradattauniversity.org
}

\begin{abstract}
Abstrak
Penelitian ini berjudul pengaruh kualitas produk dan brand image handphone samsung terhadap purchase intention konsumen pada galeri teknologi denpasar. Kecendrungan untuk memutuskan membeli produk menjadikan sebagai produk smartphone yang ditujukan kepada para pekerja bisnis yang memiliki kebutuhan akan internet, kini menjadi tidak ada batasan usia atau pekerjaan untuk dapat membelinya. Daya beli masyarakat ditentukan berdasarkan kualitas produk yang dipilih dan brand image dari produk tertentu sehingga menunjukan nilai lebih dari produk yang dibeli.

Sampel penelitian ini berjumlah 90 orang yang diambil menggunakan teknik purposive sampling. Pengumpulan data melalui kuesioner. Teknik analisis data yang digunakan adalah analisis regresi linear berganda. Hasil F-test memang benar ada pengaruh positif dan signifikan secara simultan antara kualitas produk dan brand image terhadap purchase intention konsumen pada galeri teknologi. Kuefisien korelasi berganda menyatakan bahwa ada hubungan yang positif secara simultan antara kualitas produk dan brand image dengan purchase intention konsumen. Koefision determinasi diproleh sebesar 58,2\%. Ada pengaruh yang signifikan secara parsial antara kualitas produk dan brand image pada galeri teknologi. Kualitas produk merupakan variabel dominan yang berpengaruh terhadap purchase intention konsumen pada galeri teknologi. Berdasarkan hal tersebut disarankan kepada produsen samsung agar menyediakan produk yang sesuai dengan umur pemakai, misalnya orang tua membutuhkan keypad dengan tombol yang besar. Selain itu pihak produsen melalui mitra bisnisnya agar menciotakan image yang mudah diingat oleh masyarakat memlalui media yang memiliki jaringan luas.
\end{abstract}

Kata Kunci : Kualitas Produk, brand imagedan purchase intention

\section{Abstract}

This study aims to examine the effect of product quality and brand image of samsung mobile phone to purchase intention of consumer in Denpasar technology gallery. The tendency for product purchase intentions make the smart phone as a product aimed at the businessman who has a need for the Internet, there

Ni Ketut Budiani

Ni Wayan Ari Sudiartini

A.A Elik Astari

I Dewa Nyoman Usadha 
is no age limit or a job to be able to afford it. Public purchasing power is determined based on product quality and brand image of certain products that show the value of the purchased product.

This study used 90 samples were taken using purposive sampling technique. The method of collecting data through questionnaire. Data analysis was performed with multiple linear regression analysis. The results showed by the Ftest is product quality and brand image significant positive effect on purchase intention of consumer in technology gallery. The results showed by the coefficient of multiple correlation states is product quality and brand imagesimultaneous positive effect on purchase intention of consumer in technology gallery. Coefficient of determination was obtained equal to 58,2\%. There is a partially significant influence between product quality and brand image in the technology gallery. The quality of products is the dominant variables that influence consumer purchase intention on technology gallery. Based on this suggested to the manufacturer Samsung to provide products that comply with the age of the user, such as parents need a keypad with large buttons. The producers through their business partners to create an image that is easily remembered by the public through media that has a wide network.

Keywords: product quality, brand image, purchase intention 


\section{Pendahuluan}

Di zaman era globaisasi seperti sekarang ini, kemajuan teknologi alat kualitas produk mulai diperhatikan oleh kalangan luas masyarakat. Kualitas produk berupa telepon genggam saat ini sudah bukan merupakan kebutuhan mewah lagi. Secara umum alat kualitas produk berupa telepon genggam digunakan untuk melakukan panggilan jarak jauh atau jarak dekat dengan teman atau kerabat. Dalam menggunakan telepon genggam setiap orang dapat melakukan pembicaraan dengan orang lain dan jarak yang jauh, selain itu dengan menggunakan telepon genggam juga bisa mengirimkan pesan berupa pesan singkatatau bisa disebut dengan SMS (Short Message Service). Semakin majunya zaman, telepon genggam mengalami perkembangan teknologi yang terus maju dan meningkat.Tidak hanya dapat melakukan panggilan telepon atau mengirimkan pesan singkat, tetapi juga sudah bisa mengakses internet dari genggaman tangan. Internet pada awalnya hanya dapat dilakukan dengan menggunakan computer, tapi saat ini dengan menggunakan telepon genggam juga dapat mengakses internet dimna saja.

Produk merupakan titik pusat dari kegiatan pemasaran karena produk merupakan hasil dari suatu perusahaan yangdapat ditawarkan kepasar untuk di konsumsi dan juga merupakan alat bagi suatu perusahaan untuk mencapai tujuan perusahaannya.

Dimna brand image yang terdiri dari citra perusahaan, citra konsumen, dan citra produk, pengaruh citra merek yang terdiri dari citra perusahaan, citra konsumen, dan citra produk secara parsial terhadap minat beli. Hasil penelitian menujukkan bahwa : citra perusahaan, citra konsumen, dan citra produk secara bersama-sama berpengaruh singifikan terhadap minat beli Miki Ambarwati,Sunarti (2015 Vol 25)

Merek(brand) adalah salah satu atribut yang sangat penting dari sebuah produk yang penggunaaannya pada saat ini sudah sangat meluas karena beberapa alasan, dimana merek suatu produk berati memberikan nilai tambah produk tersebut.Kualitas merupakan nilai dari suatu yang ditawarkan kepada konsumen, penting bagi perusahaan untuk membuat suatu produk dengan kualitas yang diperlihatkan. Pengertian kualitas produk menurut Kotler dan Armstrong (2014: 352) yaitu

segala sesuatu yang dapat ditawark an ke pasar untuk mendapatkan perhatian, dibeli, digunakan, atau dikonsumsi yang dapat memuaskan keinginan atau kebutuhan. Fokus utama dalam perusahaan, kualitas merupakan suatu kebijakan penting dalam meningkatkan daya saing produk yang harus memberikan kepuasan kepada konsumen yang melebihi atau paling tidak sama dengan kualitas produk dari pesaing.

Sehingga dapat disimpulkan bahwa merek(brand)mempunyai arti yang penting bagi sebuah produk serta didukung oleh kualitas yang handal dan dapat mempengaruhi niat pembelian konsumen. Hal ini didukung oleh penelitian yang dilakukan Alana, dkk (2013:8) secara

Ni Wayan Ari Sudiartini

A.A Elik Astari

I Dewa Nyoman Usadha 
signifikan desai produk berpengaruh positif, dan umtuk fitur produk secara signifikan berpengaruh positif terhadap keputusan pembelian. Dan dimana pemasaran merupakan faktor penting dalam perkembangan perusahaan. Pemasaran harus terus menerus ditingkatkan dan diperbaharui, hal ini tentunya tidak terlepas dari kebutuhan dan keinginan konsumen tersebut Cristy Jacklin Gerung, Jantje Sepang dan Sjendry Loindong (2017 Vol.5)

$$
\text { Persepsi mendasari }
$$

seseorang untuk melakukan purchase intention terhadap apa yang diinginkan.Konsumen akan menampakkan perilakunya setelah melakukan persepsi terhadap keputusan apa yang akan diambil dalam membeli suatu produk. Menurut Schiffman dan Kanuk dalam (Wahyuni,2008:31) "Perception isa process by which an individual selects, organizers and interprets stimuli into the a meaningfull and coherentpicture of the world". Kurang lebihnya bahwa persepsi merupakan suatu proses yang membuat seseorang untuk memilih, mengorganisasikam, dan menginterpretasikan rangsanganrangsangan yang diterima menjadi suatu gambaran yang berarti dan lengkap tentang duniannya. Persepsi kualitas dapat didefi isikan sebagai persepsi pelanggan terhadap kualitas produk secara keseluruhan berkenaan dengan maksud yang diharapkan, dimana bersifat relatif terhadap alternaif-alternatif.

Galeri Teknologi merupakan satu diantara sekian banyak perusahaan yang bergerak dalam bidang penjualan handphone yang berlokasi di Jalan Raya Sempidi No. 9 .Kegiatan promosi penjualanyang dilakukan oleh Galeri Teknologi adalah direct selling team. Dimana direct selling team adalah penjualan langsung yang dilakukan oleh team yang terdiri dari SPG dan team leader ke target konsumen yang ada di public area. Kegiatan bauran pemasaran yang dilaksanakan oleh Galeri Teknologi menghasilkan sejumlah biaya yang diharapkan akanmeningkatkan volume penjualan dan nilai penjualan. Volume penjualan merupakan hasil dari kegiatan penjualan produk yang dilakukan oleh perusahaan Galeri Teknologi ke tangan konsumen dalam usaha mencapai sasaran yaitu memaksimalkan laba dalam periode tertentu.Adapun data volume penujualan dan nilai penjualan dapat dilihat pada tabel berikut

\section{Tabel}

Jumlah Produk yang Terjual Menurut Jenis Produk Handphone PadaGaleri Teknologi

Tahun 2012-2017

\begin{tabular}{|c|c|c|c|c|c|c|}
\hline No & Tahun & $\begin{array}{c}\text { Nokia } \\
\text { (produk) } \\
\text { /unit }\end{array}$ & $\begin{array}{c}\text { Blackberry } \\
\text { (produk) } \\
\text { /unit }\end{array}$ & $\begin{array}{c}\text { Samsung } \\
\text { (produk) } \\
\text { /unit }\end{array}$ & $\begin{array}{c}\text { Iphone } \\
\text { (produk) } \\
\text { /unit }\end{array}$ & $\begin{array}{c}\text { Asus } \\
\text { (produk) } \\
\text { /unit }\end{array}$ \\
\hline 1 & 2012 & 6.232 & 4.320 & 4.320 & 1.265 & 2.189 \\
\hline 2 & 2013 & 6.123 & 5.010 & 4.475 & 1.032 & 2.458 \\
\hline 3 & 2014 & 6.280 & 5.125 & 5.491 & 1.027 & 2.657 \\
\hline
\end{tabular}

Ni Ketut Budiani

Ni Wayan Ari Sudiartini

A.A Elik Astari

I Dewa Nyoman Usadha 


\begin{tabular}{|c|c|c|c|c|c|c|}
\hline 4 & 2015 & 6.240 & 4.132 & 5.568 & 1.547 & 2.342 \\
\hline 5 & 2016 & 6.345 & 3.997 & 6.893 & 1.884 & 2.249 \\
\hline 6 & 2017 & 6.213 & 3.426 & 7.456 & 1.983 & 2.230 \\
\hline \multicolumn{2}{|c|}{ Jumlah } & $\mathbf{3 7 . 4 3 3}$ & $\mathbf{2 6 . 0 1 0}$ & $\mathbf{3 4 . 2 0 8}$ & $\mathbf{8 . 7 3 8}$ & $\mathbf{1 4 . 1 2 5}$ \\
\hline \multicolumn{2}{|c|}{ Rata-rata } & $\mathbf{6 . 2 4}$ & $\mathbf{4 . 3 3}$ & $\mathbf{5 . 7 0}$ & $\mathbf{1 . 4 5}$ & $\mathbf{2 . 3 5}$ \\
\hline
\end{tabular}

Sumber : Galeri Teknologi

Dari tabel 1 dapat dijelaskan jumlah masing-masing jenis produk yang laku dari tahun 2012 sampai dengan 2017berfluktuasi, jumlah produk yang terjual rata-rata setiap tahunnya untuk masing-masing produk handphone secara berurutan dari yang terbesar adalah: Nokia sebanyak 6.24 produk, Samsung sebanyak 5.70 produk, Blackberry sebanyak 4.33 produk, Asus sebanyak 2.35 produk, serta Iphone sebanyak 1.45 produk.

Adapun jumlah konsumen dan nilai penjualan pada Galeri Teknologi dari tahun 2012 sampai dengan 2017 dapat dilihat dari tabel sebagai berikut:

Tabel 1.2

Jumlah Konsumen dan Nilai Penjualan Pada Galeri Teknologi Tahun 2012-2017

\begin{tabular}{|c|c|c|c|c|c|}
\hline No & Tahun & $\begin{array}{c}\text { Jumlah } \\
\text { Konsumen } \\
\text { (orang) }\end{array}$ & $\begin{array}{c}\text { Nilai penjualan } \\
\text { (Rp) }\end{array}$ & $\begin{array}{c}\text { Perubahan } \\
\text { Jumlah } \\
\text { Konsumen } \\
(\%)\end{array}$ & $\begin{array}{c}\text { Perubahan } \\
\text { Nilai } \\
\text { Penjualan } \\
(\%)\end{array}$ \\
\hline 1 & 2012 & 18.320 & 48.411 .497 .680 & - & - \\
\hline 2 & 2013 & 19.472 & 51.455 .714 .128 & 6,29 & 6,29 \\
\hline 3 & 2014 & 20.206 & 53.395 .345 .094 & 3,77 & 3,77 \\
\hline 4 & 2015 & 21.325 & 56.352 .357 .425 & 5,54 & 5.54 \\
\hline 5 & 2016 & 21.011 & 55.522 .597 .039 & $-1,47$ & $-1,47$ \\
\hline 6 & 2017 & 21.812 & 55.841 .438 .146 & 3,81 & 0,57 \\
\hline \multicolumn{2}{|c|}{ Jumlah } & $\mathbf{1 2 2 . 1 4 6}$ & $\mathbf{3 2 0 . 9 7 8 . 9 4 9 . 5 1 2}$ & $\mathbf{1 7 , 9 4}$ & $\mathbf{1 4 , 7}$ \\
\hline \multicolumn{2}{|c|}{ Rata-rata } & $\mathbf{2 0 . 3 5 7}$ & $\mathbf{5 3 . 4 9 6 . 4 9 1 . 5 8 5}$ & $\mathbf{2 , 9 9}$ & $\mathbf{2 , 4 5}$ \\
\hline
\end{tabular}

Sumber : Galeri Teknologi 
Dari data tabel 2 dapat dijelaskan jumlah konsumen dan nilai penjualan pada Galeri Teknologi pada tahun 2012 sampai dengan 2017 mencapai rata-rata pertahun 20.357 orang sedangkan rata-rata nilai penjualan dari tahun 2012 sampai dengan 2017 mencapai Rp. 53.496.491.585 Selain

itu jumlah konsumen terus berfluktuasi yaitu pada tahun 2016 sebesar $1,47 \%$ pada tahun 2017 sebesar $3,81 \%$. Nilai penjualan juga mengalami fluktuasi yaitu pada tahun 2016 sebesar $1,47 \%$ dan pada tahun 2017 sebesar $0,57 \%$.

\section{Perumusan Masalah}

Berdasarkan latar belakang masalah yang telah diuraikan, dapat dirumuskan pokok masalah penelitian sebagai berikut:

1) Apakah kualitas produk dan brand image berpengaruh secara simultan terhadap purchase intentionkonsumen pada Galeri Teknologi di Sempidi?

2) Apakah kualitas produk dan brand image berpengaruh secara parsial terhadap purchase intention konsumen pada Galeri Teknologi di Sempidi?

Variabel manakah yang paling berpengaruh dominan terhadap purchase intention konsumen pada Galeri Teknologi di Sempidi? Tinjauan Pustaka

\section{Pemasaran}

Pemasaran merupakan faktor penting dalam perkembangan perusahaan.Pemasaran harus terus menerus ditingkatkan dan diperbaharui, hal ini tentunya tidak terlepas dari kebutuhan dan keinginan konsumen tersebut Cristy Jacklin Gerung, Jantje Sepang dan Sjendry Loindong (2017 Vol.5).Perubahan selera konsumen, lingkungan ekonomi dan persangian yang semakin tajam membuat peranan pemasaran sangat penting untuk mempertahankan kelangsungan hidupnya untuk berkembang dan mendapatkan laba rugi perusahaan.Peran pemasaran sangat pentimg untuk megetahui keinginan konsumen dan perusahaan berusaha memenuhinya. Perusahaan banyak yang memproduksi barang yang sejenis, sehingga membuat konsumen lebih selektif dalam memilih produk mana yang akan digunakan untuk memenuhi kebutuhannya. Para pakar bidang pemasaran telah mengemukan pendapatnya mengenai pemasaran.

3) Pengertian Produk

Produk dihasilkan untuk pemuasan kebutuhan dan keinginan dari konsumen.Produsen harus memperhatikan kebijakan yang ditetapkan atas produk yang dihasilkan. Produk pada dasarnya dapat diklasifikasikan dengan berbagai cara, antara lain berdasarkan pada daya tahan produk dalam penggunaannya atau wujud produk tersebut.

Menurut Kotler (2009:42), produk dapat dikelompokan menjadi tiga yaitu:

1) Non-durable goods (barang yang tidak bertahan lama), yaitu barang yang dikonsumsi sekali pakai atau memiliki jangka waktu kurang dari satu tahun.

Ni Wayan Ari Sudiartini

A.A Elik Astari

I Dewa Nyoman Usadha 
2) Durable goods (barang yang dapat bertahan lama), yaitu barang yang bersifat tahan lama dan dapat dipergunakan lebih dari satu tahun.

3) Services (jasa, yaitu suatu aktivitas, manfaat atau kepuasan yang ditawarkan oleh suatu perusahaan untuk dijual.

Definisi di atas dapat disimpulkan bahwa produk yang ditawarkan kepada konsumen bertujuan untuk memenuhi kebutuhan konsumen.Perusahaan mengharapkan pemenuhan kebutuhan konsumen dapat mendatangkan keuntungan yang maksimal.Karena produk yang ditawarkan perusahaan mampu memenuhi ke inginan pasar sesuai dengan kompetisi, kapasitas organisasi dan daya beli pasar.

Pengertian merek

Suatu produk dapat dibedakan dari produk lainnya dari segi merek (brand). Merek dapat dipakai sebagai alat untuk menciptakan pandangan tertentu dari para pembeli baik melalui periklanan maupun kegiatan promosi yang dilakukan.

Menurut Kotler dan Keller (2011:263) merek merupakan suatu nama, symbol, tanda, atau desain atau kombinasi diantaranya, dan ditujukan untuk mengidentifikasi barang atau jasa dari seorang penjual atau kelompok penjual dan untuk membedakan dari para pesaing.

2.3.2 Tujuan merek

Penggunaan

merek

mempunyai beberapa tujuan, yaitu:

1) Sebagai identitas perusahaan yang membedakannya dengan produk pesaing, sehingga konsumen mudah untuk mengenali dan melakukan pembelian ulang.

2) Sebagai alat promosi yang menonjolkan daya tarik produk.

3) Untuk membina image yaitu dengan memberikan keyakinan, jaminan kualitas, serta citra prestise tertentu terhadap konsumen.

4) Untuk mengendalikan dan mendominasikan pasar artinya dengan membangun merek yang terkenal, image yang baik dan dilindungi oleh hak eksklusif berdasarkan hak cipta/paten, maka perusahaan dapat meraih dan mempertahankan loyalitas konsumen.

\section{Minat Beli(purchase intention)}

Kotler dan Keller (dalam Adi 2015:36) menyatakan bahwa minat beli konsumen merupakan sebuah perilaku konsumen dimana konsumen memiliki keingina untuk memilih, menggunakan, mengkonsumsi atau bahkan menginginkan suatu produk yang ditawarkan.

1) Keputusan tentang jenis produk Konsumen dapat mengambil keputusan untuk membeli sebuah produk atau menggunakan uangnya untuk tujuan yang lain. Dalam hal ini perusahaan memberikan alternative lainnya yang akan dipertimbangkan konsumen.

2) Keputusan tentang bentuk produk

Konsumen dapat mengambil keputusan untuk membeli atau

Ni Wayan Ari Sudiartini

A.A Elik Astari

I Dewa Nyoman Usadha 
$\begin{array}{lr}\text { menggunakan } & \text { produk } \\ \text { tertentu.Pemasar } & \text { harus } \\ \text { mengetahui } & \text { kesukaan } \\ \text { konsumen tentang produk yang } & \text { untuk } \\ \text { bersangkutan } & \text { undan } \\ \text { memaksimumkan daya tari. }\end{array}$

3) Keputusan tentang penjualnya Konsumen harus mengambil keputusan dimana akan membeli produk yang dibutuhkan.

4) Keputusan tentang jumlah produk

Konsumen akan mengambil keputusan tentang berapa jumlah produk yang akan dibeli. Pembelian yang dibeli mungkin lebih dari satu unit.Perusahaan harus mempersiapkan banyak produk untuk memenuhi keinginan dan kebutuhan yang berbeda antar konsumen.

5) Keputusan tentang waktu pembelian.

Konsumen akan memutuskan kapan sesorang membeli suatu produk. Masalah ini berkaitan dengan

keuangannya.Perusahaan harus megetahui faktor-faktor yang mempengaruhi keputusan konsumen dalam waktu pembelian, sehingga perusahaan tahu kapan permintaan puncak da permintaan sepi.

6) Keputusan tentang cara pembayaran

Konsumen harus mengambil keputusan tentang bagaimana cara pembayaran yang akan dilakukan untuk transaksi. Perusahaan harus mengetahui keinginan konsumen tentang cara pembayaran.

Tahap-tahap dalam proses keputusan membeli menurut Kotler (2010:89) :

1) Pengenalan masalah

Konsumen memulai proses pembelian ketika menyadari merasakan adanya masalah atau kebutuhan. Konsumen merasakan suatu perbedaan antara kedaan yang sekarang dan keadaan yang diinginkanya.Kebuuhan ini dapat dipicu oleh rangsangan internal/eksternal.Perusahaan perlu menentukan faktorfaktor dan situasi yang biasanya memicu minat konsumen, dan menyusun program pemasaran yang menyangkut rangsangan ini.

2) Pencarian informasi

Seseorang yang terdorong oleh kebutuhan akan melakukan proses pembelian lebih lanjut. Pencarian informasi mengenai sumbersumber dan nilainya.

3) Penilaian dan seleksi terhadap alternative pembelian

Pemasar perlu mengetahui bagaimana konsumen memproses informasi untuk sampai pada pilihannya.

Konsumen akan menggunakan perhitungan yang cermat dan logis. Atas dasar tujuan pembelian yang telah diidentifikasikan, dinilai dan diseleksi menjadi alternatif pembelian yang dapat memebuhi dan 
memuaskan kebutuhan serta keinginannya.

4) Keputusan tentang merek Konsumen akan memilih merek mana yang akan dibeli, setiap merek meniliki perbedaan dalam kelebihan dan kelemahannya. Perusahaan harus mengetahui bagaimana konsumen memilih sebuah merek.

5) Keputusan pembelian Keputusan untuk membeli disini merupakan proses dalam pembelian nyata. Jadi, setelah tahap-tahap dimuka dilakukka, maka konsumen harus mengambil keputusan apakah membeli atau tidak. Bila konsumen memutuskan untuk membeli, konsumen akan menjumpai serangkaian keputusan yang harus diambil menyangkut jenis produk, merek, penjual, kuantitas, waktu pembelian, dan cara pembayarannya. Tahap ini konsumen akan memilih penjual yang terbaik untuk membeli barang yang dibutuhkannya.

6) Perilaku purna pembelian

Tujuan pemasar tidak berakhir pada saat produk sudah dibeli tetapi berlanjut sampai periode sesudah pembelian. Konsumen akan merasakan kepuasan atau ketidakpuasan setelah membeli produk atau jasa. Kepuasan akan meninmbulkan pembelian ulang dan ketidakpuasan menjauhkan konsumen lain atau calon konsumen. Perusahaan hendaknya teratur mengukur tingkat kepuasan pelanggan agar dapat diketahui apabila ada yang kurang dalam pelayannya.

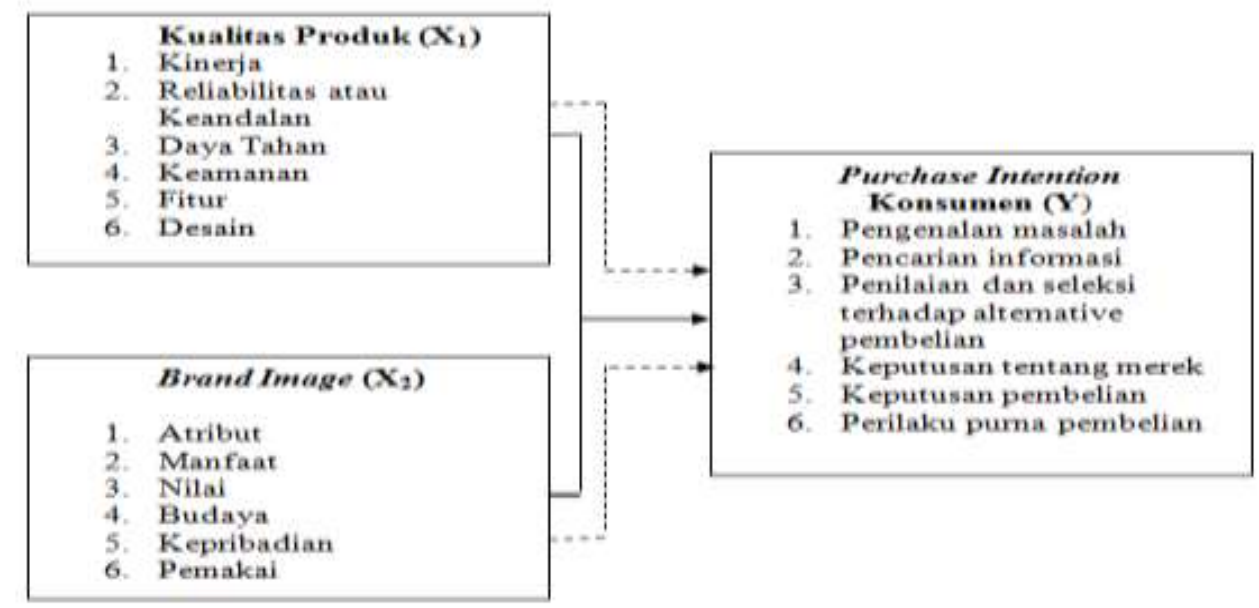




\section{Metodologi Penelitian}

Sampel

Sampel adalah subkelompok populasi yang terpilih untuk berpartisipasi dalam studi. Untuk memproleh sampel yang representative dari populasi, maka setiap subjek dalam populasi diupayakan memiliki peluang yang sama untuk menjadi sampel. Pengambilan sampel dalam penelitian ini menggunakan teknik purposive sampling. Purposive sampling adalah teknik penentuan sampel dengan pertimbangan tertentu, yaitu anggota populasi yang dipilih sabagai sampel adalah konsumen Galeri Teknologi yang berusia 17 tahun keatas dengan pertimbangan dianggap memahami dan mampu menjawab kuesioner. Dalam penelitian ini menggunakan 18 indikator sehingga banyaknya responden yang digunakan sebagai sampel adalah $5 \times 18=90$ orang.Indikator yang digunakan sesuai dengan jumlah indikator yang terdapat pada kerangka pemikiran sedangkan nilai 5 merupakan nilai tertinggi dari skala likert yang digunakan.Menurut Sugiyono dalam (Agus Suriadi, 2015:42).

\section{Lokasi penelitian}

Penelitian ini dilakukan di outlet Galeri Teknologiyang beralamat di Jalan Raya Sempidi 09 Mangupura-Denpasar. Pemilihan lokasi dilakukan dengan metode purposive sampling, yaitu pemilihan lokasi penelitian secara sengaja atas pertimbngan-pertimbangan tertentu. Dasar pertimbangan penentuan lokasi di Galeri Teknologi yang beralamat di
Jalan Raya Sempidi 09 mangapuraDenpasar adalah

a. Outlet Galeri Teknologi merupakan salah satu dari sekian banyak outlet yang menjual handphone merek samsung di wilayah Denpasar.

b. Sampai saat ini belum pernah dilakukan penelitian dengan judul yang sama di outlet tersebut.

c. Peneliti dapat izin untuk melakukan penelitian di outlet Galeri Teknologi di Denpasar.

\section{Metode Pengumpulan Data}

Pengumpulan data yang dilakukan dalam penelitian ini adalah menggunakan metode survei dengan dua cara untuk pengumpulan data yaitu sebagai berikut :
a. Data Primer
b. Observasi
c. Wawancara
d. Kuesioner
e. Data Sekunder
f. Studi Pustaka
g. Studi Dokumen

\section{Teknik Analisis Data}

a. Uji Validitas Instrumen Penelitian

Uji Validitas yaitu pengujian tingkat ketepatan menggunakan alat pengukur terhadap suatu gejala atau kejadian.

b. Uji Reliabilitas

Uji Reliabitas yaitu istilah yang dipakai untuk menunjukan sejauh mana suatu hasil pengukur relatif konsisten apabila pengukuran dilakukan dua kali atau lebih.

c. Analisis Asumsi Klasik 
- Uji Normalitas

Uji ini bertujuan untuk menguji apakah dalam model regrasi variabel pengganggu atau residual memiliki distribusi normal.

- Uji Multikolinieritas Uji ini bertujuan untuk menguji apakah dalam model regrasi ditemukan adanya korelasi antar variabel bebas (variabel independent).

- Uji Heteroskedastisitas Uji ini bertujuan untuk menguji apakah dalam suatu model regresi terjadi ketidaksamaan varians dari residual satu pengamatan ke pengamatan lain.

- Analisis Korelasi Berganda

Analisis korelasi berganda merupakan perluasan dari analisis korelasi sederhana.

- Uji Koefisien Determinasi $\left(\mathrm{R}^{2}\right)$

Uji koefisien determinasi $\left(\mathrm{R}^{2}\right)$ digunakan untuk mengukur seberapa jauh kemampuan model dalam menerangkan variasi variabel dependen.

- Uji Serentak (Uji F)

Uji $F$ digunakan untuk menguji apakah model regresi dapat digunakan untuk memprediksi variabel dependen. Jika angka signifikansi lebih kecil dari 0,05 maka model regresi layak digunakan untuk memprediksi variabel dependen (Ghozali,2001 : 47).

- Uji Parsial (Uji t)
Uji t dilakukan untuk melihat seberapa jauh pengaruh variabel independent secara individu dalam menerangkan variasi variabel dependent (Ghozali,2001:48).

\section{Pembahasan}

Galeri Teknologi adalah salah satu unit usaha dari Raditya Holding Company yang mengkhususkan diri untuk bergerak dibidang penjualan segala kebutuhan masyarakat akan peralatan-peralatan yang berhubungan dengan teknologi khususnya HandphoneTeknologi Informasi (IT). Dengan pendirinya adalah Bapak Made Sudiana,SH.

Sebagai pelaku usaha dibidang Teknolog iInformasi (Hardware dan Software) tentu beberapa aktifitas yang berkaitan dengan Teknologi Informasi dilakukan disini,dalam rangka membantu masyarakat memenuhi kebutuhannya, seperti membentuk divisi untuk pelayanan service dan perbaikan terhadap semua peralatan yang berhubungan dengan teknologi informasi, memberikan kesempatan praktek kerja terhadap para siswa yang akan melakukan praktek kerja, dalam usaha menyelaraskan pengetahuan skill siswa dengan kebutuhan pelaku usaha.

\section{Deskripsi Data}

Untuk mengetahui persepsi responden mengenai kualitas produk, brand image terhadap purchase intention konsumen pada Galeri Teknologi, maka dilakukan penelitian dengan cara menyebarkan kuesioner yang secara umum berisi persepsi responden terhadap kualitas produk, brand image, dan purchase intention pada Galeri Teknologi. Model 
kuesioner yang disebar menggunakan skala likert 1-5.

Kuesioner diberikan dan disebarkan kepada responden pada Galeri Teknologi sesuai dengan kebutuhan yaitu sebanyak 90 orang. Selanjutnya, dari hasil jawaban responden mengenai kualitas produk, citra merek keputusan pembelian konsumen dibuat kedalam tabel rekapitulasi agar bisa dilakukan pengujian. Uji kuesioner dalam penelitian ini meliputi uji validasi dan reliabilitas instrumen penelitian.

Karakteristik Responden

Karakteristik responden dalam penelitian ditinjau dari segi jenis kelamin, umur, dan tingkat pendidikan.

Tabel 4.5

Karakteristik Responden Pada Bali Trade Centre (BTC) Mobile Phone

\begin{tabular}{|c|l|l|c|c|}
\hline No & Karakteristik & Pilihan & Frekuensi & Persentase \\
\hline 1 & Jenis kelamin & Laki-laki & 50 & 55,6 \\
& & Perempuan & 40 & 44,4 \\
\hline & Jumlah & & 90 & 100 \\
\hline 2 & Umur & 20-30 tahun & 40 & 44,4 \\
& & $31-40$ tahun & 35 & 38,9 \\
& & $>40$ tahun & 15 & 16,7 \\
\hline & Jumlah & & 90 & 100 \\
\hline \multirow{2}{*}{3} & Pendididkan & SMA/sederajat & 10 & 11,1 \\
& & Diploma/PT & 80 & 88,9 \\
\hline & Jumlah & & 90 & 100 \\
\hline
\end{tabular}

Sumber data diolah, 2018 


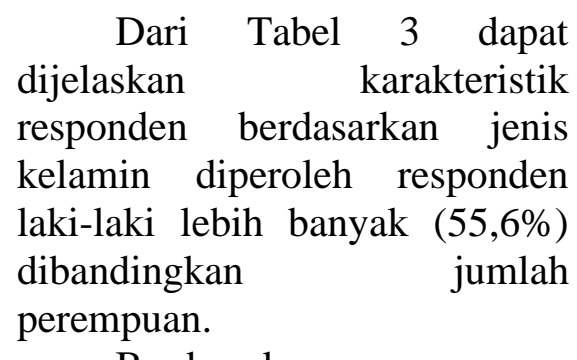

Berdasarkan umur diperoleh responden umur 31-40 tahun sebanyak 35 orang $(38,9 \%)$, umur $>40$ tahun sebanyak 15 orang $(16,7 \%)$, umur 20-30 tahun sebanyak 40 orang $(44,4 \%)$.

Berdasarkan tingkat pendidikan diperoleh tingkat pendidikan reponden yang terbanyak adalah Diploma/PT sebanyak 80 orang $(88,9 \%)$.

\section{Analisis kuantitatif variabel kualitas produk $\left(\mathbf{X}_{1}\right)$}

Berdasarkan hasil perhitungan, diketahui bahwa sebagian besar jawaban responden adalah kategori Ragu-ragu (RG) yaitu sebesar 47,41\%, diikuti jawaban Setuju (S) sebesar 28,33\%, selanjutnya jawaban Tidak Setuju (TS) sebesar 24,26\%, dan tidak ada jawaban Sangat Tidak Setuju (STS) dan jawaban Sangat Setuju (SS). Maka dari itu dapat dijelaskan bahwa nilai yang dimiliki handphone merek Samsung yang belum dirasakan secara langsung oleh konsumen pada Galeri Teknologi dalam penggunaannya.

Analisis kuantitatif variabel citra merek $\left(\mathbf{X}_{2}\right)$

\section{Uji Validitas}

Tanggapan responden terhadap variabel citra merek seperti yang tertera pada tabel 4.2 di atas, diketahui bahwa sebagian besar jawaban responden adalah kategori Ragu-ragu (RG) yaitu sebesar 48,33\%, diikuti jawaban Setuju (S) sebesar 39,44\%, selanjutnya jawaban Tidak Setuju (TS) sebesar 12,22\%, dan tidak ada jawaban Sangat Tidak Setuju (STS) dan jawaban Sangat Setuju (SS). Maka dari itu dapat dijelaskan bahwa persepsi konsumen terhadap handphone Samsung dimana ciri khas dari handphone Samsung tidak tergambar dengan jelas dari mereknya sehingga sedikit sulit diingat oleh konsumen.

\section{Analisis kuantitatif variabel keputusan pembelian (Y)}

Sebaran data tanggapan keputusan pembelian sebagaimana yang tertera pada tabel 4.3 di atas, diketahui bahwa sebagian besar jawaban responden adalah kategori Setuju (S) yaitu sebesar 62,59\%, diikuti jawaban Ragu-ragu (RG) sebesar $36,3 \%$, selanjutnya jawaban Sangat Setuju (SS) sebesar 1,11\%, dan tidak ada jawaban Sangat Tidak Setuju (STS) dan jawaban Tidak Setuju (TS). Maka dari itu dapat dijelaskan bahwa sikap konsumen pada Galeri Teknologi untuk membeli atau menggunakan produk Samsung adalah baik dan konsumen bersedia menanggung resiko yang mungkin ditimbulkan setelah handphone yang dibeli.

\section{Hasil Uji Validitas}

Ni Wayan Ari Sudiartini

A.A Elik Astari

I Dewa Nyoman Usadha 


\begin{tabular}{|l|c|c|c|c|}
\hline Variabel & Item & R Hitung & R Tabel & Keterangan \\
\hline \multirow{4}{*}{ Kualitas Produk } & 1 & 0,842 & 0,30 & Valid \\
\cline { 2 - 5 } & 2 & 0,852 & 0,30 & Valid \\
\cline { 2 - 5 } & 3 & 0,526 & 0,30 & Valid \\
\cline { 2 - 5 } & 4 & 0,765 & 0,30 & Valid \\
\cline { 2 - 5 } & 5 & 0,856 & 0,30 & Valid \\
\hline \multirow{4}{*}{ Citra Merek } & 6 & 0,809 & 0,30 & Valid \\
\cline { 2 - 5 } & 1 & 0,550 & 0,30 & Valid \\
\cline { 2 - 5 } & 2 & 0,777 & 0,30 & Valid \\
\cline { 2 - 5 } & 3 & 0,815 & 0,30 & Valid \\
\cline { 2 - 5 } & 4 & 0,820 & 0,30 & Valid \\
\hline \multirow{4}{*}{\begin{tabular}{l} 
Keputusan \\
\cline { 2 - 5 }
\end{tabular}} & 5 & 0,819 & 0,30 & Valid \\
\cline { 2 - 5 } & 1 & 0,845 & 0,30 & Valid \\
\cline { 2 - 5 } & 2 & 0,731 & 0,30 & Valid \\
\cline { 2 - 5 } & 3 & 0,703 & 0,30 & Valid \\
\cline { 2 - 5 } & 4 & 0,788 & 0,30 & Valid \\
\cline { 2 - 5 } & 5 & 0,717 & 0,30 & Valid \\
\hline
\end{tabular}

Berdasarkan hasil pengujian pada tabel di atas diketahui bahwa semua item memiliki nilai $r>0,30$. Nilai tersebut menunjukkan bahwa instrumen ini valid digunakan sebagai alat ukur penelitian.

\section{Uji Reliabilitas}

\section{Hasil Uji Reliabilitas}

\begin{tabular}{|c|c|c|c|c|}
\hline \multirow{4}{*}{ Variabel } & Item & $\begin{array}{c}\text { Cronbach } \\
\text { alpa } \\
\text { Hitung }\end{array}$ & $\begin{array}{c}\text { Cronbach } \\
\text { alpa } \\
\text { Minimal }\end{array}$ & Keterangan \\
\hline \multirow{5}{*}{ Kualitas Produk } & 1 & 0,834 & 0,60 & Reliabel \\
\cline { 2 - 5 } & 2 & 0,829 & 0,60 & Reliabel \\
\cline { 2 - 5 } & 3 & 0,892 & 0,60 & Reliabel \\
\cline { 2 - 5 } & 4 & 0,849 & 0,60 & Reliabel \\
\cline { 2 - 5 } & 5 & 0,829 & 0,60 & Reliabel \\
\cline { 2 - 5 } & 6 & 0,841 & 0,60 & Reliabel \\
\hline \multirow{5}{*}{ Citra Merek } & 1 & 0,883 & 0,60 & Reliabel \\
\cline { 2 - 5 } & 2 & 0,846 & 0,60 & Reliabel \\
\cline { 2 - 5 } & 3 & 0,836 & 0,60 & Reliabel \\
\cline { 2 - 5 } & 4 & 0,835 & 0,60 & Reliabel \\
\cline { 2 - 5 } & 5 & 0,837 & 0,60 & Reliabel \\
\cline { 2 - 5 } & 6 & 0,829 & 0,60 & Reliabel \\
\hline & 1 & 0,775 & 0,60 & Reliabel \\
\hline
\end{tabular}




\begin{tabular}{|l|c|c|c|c|}
\hline Variabel & Item & $\begin{array}{c}\text { Cronbach } \\
\text { alpa } \\
\text { Hitung }\end{array}$ & $\begin{array}{c}\text { Cronbach } \\
\text { alpa } \\
\text { Minimal }\end{array}$ & Keterangan \\
\hline \multirow{3}{*}{$\begin{array}{l}\text { Keputusan } \\
\text { Pembelian }\end{array}$} & 2 & 0,758 & 0,60 & Reliabel \\
\cline { 2 - 5 } & 3 & 0,770 & 0,60 & Reliabel \\
\cline { 2 - 5 } & 4 & 0,737 & 0,60 & Reliabel \\
\cline { 2 - 5 } & 5 & 0,756 & 0,60 & Reliabel \\
\cline { 2 - 5 } & 6 & 0,779 & 0,60 & Reliabel \\
\hline
\end{tabular}

Hasil pengujian reliabilitas berdasarkan nilai Cronbach Alpha di atas didapatkan nilai variabelkualitas produk, citra merek, dan keputusan Analisis Regreasi Linier Berganda

\section{Analisis Regreasi Linier Berganda}

Coefficients $^{\mathbf{a}}$

\begin{tabular}{|ll|r|r|r|r|r|}
\hline \multirow{2}{*}{ Model } & \multicolumn{2}{|c|}{$\begin{array}{c}\text { Unstandardized } \\
\text { Coefficients }\end{array}$} & $\begin{array}{c}\text { Standardized } \\
\text { Coefficients }\end{array}$ & \multirow{2}{*}{$\mathrm{t}$} & \multirow{2}{*}{ Sig. } \\
\cline { 2 - 4 } & \multicolumn{1}{c|}{ B } & Std. Error & \multicolumn{1}{c|}{ Beta } & & \\
\hline 1 & (Constant) & 9,585 & 1,134 & & 8,454 &, 000 \\
& Kualitas Produk & 0,323 & 0,043 & 0,526 & 7,528 &, 000 \\
& Citra Merek & 0,327 & 0,046 & 0,492 & 7,051 &, 000 \\
\hline
\end{tabular}

Dependent Variable: Keputusan Pembelian

Hasil pengujian pada tabel

4.6 di atas dapat dimasukkan ke dalam persamaan:

$$
\mathrm{Y}=9,585+0,323+0,327
$$

Persamaan di atas dapat dijelaskan sebagai berikut:

1. Konstanta $a=9,585$

Apabila variabel independen yaitu kualitas produk dan citra merek tidak ada atau nilainya sama dengan nol maka keputusan pembelian nilainya adalah sebesar 9,585.

pembelian $>0,60$. hasil tersebut dapat disimpulkan bahwa instrumen ini reliabel.

Uji Statistik F (F-test)

\section{Uji Statistik F (F-Test)}

2. Koefisien regresi $\beta 1=0,323$

Apabila variabel kualitas produk meningkat satu satuan atau lebih baik maka keputusan pembelian akan ikut meningkat sebesar 0,323 dengan asumsi variabel lain tetap.

3. Koefisien regresi $\beta 2=0,327$

Apabila variabel citra merek meningkat satu satuan atau lebih baik maka keputusan pembelian akan ikut meningkat sebesar 0,327 dengan asumsi variabel lain tetap.

\begin{tabular}{|l|c|r|r|r|c|}
\hline \multicolumn{1}{|c|}{ ANOVA $^{\text {a }}$} \\
\hline 1 & $\begin{array}{c}\text { Sum of } \\
\text { Squares }\end{array}$ & Df & Mean Square & F & Sig. \\
\hline Regression & 219,386 & & 109,693 & 60,591 &, $000^{\mathrm{b}}$ \\
\hline
\end{tabular}

Ni Wayan Ari Sudiartini

A.A Elik Astari

I Dewa Nyoman Usadha 


\begin{tabular}{|l|r|r|r|r|r|}
\hline Residual & 157,503 & 87 & 1,810 & & \\
Total & 376,889 & 89 & & & \\
\hline
\end{tabular}

a. Dependent Variable: Keputusan Pembelian

b. Predictors: (Constant), Citra Merek, Kualitas Produk

Berdasarkan hasil pengujian seperti yang tertera pada tabel $4.7 \mathrm{di}$ atas didapatkan nilai $\mathrm{F}$ hitung sebesar 60,591 dengan taraf signifikansi sebesar 0,000. Nilai F hitung 60,591

$>\mathrm{F}$ tabel 3,10 sehingga Ho ditolak.
Maka dari itu dapat disimpulkan ada pengaruh positif secara simultan antara pengaruh kualitas produk dan citra merek terhadap keputusan pembelian.

Uji Statistik t (t-test)

Uji Statistik t (T-Test)

\begin{tabular}{|l|r|r|r|r|r|}
\hline \multirow{2}{*}{ Model } & \multicolumn{2}{|c|}{$\begin{array}{c}\text { Unstandardized } \\
\text { Coefficients }\end{array}$} & $\begin{array}{c}\text { Standardized } \\
\text { Coefficients }\end{array}$ & \multirow{2}{*}{$\mathrm{t}$} & \multirow{2}{*}{ Sig. } \\
\cline { 2 - 4 } & \multicolumn{1}{|c|}{ B } & Std. Error & \multicolumn{1}{c|}{ Beta } & & \\
\hline 1 (Constant) & 9,585 & 1,134 & & 8,454 &, 000 \\
$\quad$ Kualitas &, 323 &, 043 &, 526 & 7,528 &, 000 \\
$\quad$ Produk &, 327 &, 046 &, 492 & 7,051 &, 000 \\
\hline
\end{tabular}

a. Dependent Variable: Keputusan Pembelian

Berdasarkan hasil pengujian di atas dapat ditarik beberapa kesimpulan berikut:

Pengaruh kualitas produk terhadap keputusan pembelian

Hasil pengujian pada tabel 4.8 di atas menunjukkan nilai t hitung sebesar 7,528dengan taraf signifikansi 0,000 . Nilai $\mathrm{T}$ hitung 7,528> t tabel 1,98 sehingga Ho ditolak. Maka dari itu dapat disimpulkan bahwa ada pengaruh positif kualitas produk terhadap keputusan pembelian.

Pengaruh citra merek terhadap keputusan pembelian

Hasil pengujian pada tabel 4.8 di atas menunjukkan nilai t hitung sebesar 7,051dengan taraf signifikansi 0,000 . Nilai $\mathrm{T}$ hitung 7,051> t tabel 1,98 sehingga Ho ditolak. Maka dari itu dapat disimpulkan bahwa ada pengaruh positif citra merek terhadap keputusan pembelian.

Ni Wayan Ari Sudiartini

A.A Elik Astari

I Dewa Nyoman Usadha 
Jurnal Satyagraha, Vol. 02, No. 02, Agustus 2019 - Januari 2020 ISSN :2620-6358

Analisis Koefisien Determinasi

Analisis Koefisien Determinasi

Model Summary

\begin{tabular}{|l|c|r|r|r|}
\hline Model & $\mathrm{R}$ & R Square & $\begin{array}{c}\text { Adjusted R } \\
\text { Square }\end{array}$ & $\begin{array}{l}\text { Std. Error of } \\
\text { the Estimate }\end{array}$ \\
\hline 1 &, $763^{\mathrm{a}}$ &, 582 &, 572 & 1,34550 \\
\hline
\end{tabular}

a. Predictors: (Constant), Citra Merek, Kualitas Produk

Berdasarkan hasil pengujian di atas didapatkan nilai koefisien determinasi $\left(\mathrm{R}^{2}\right)$ sebesar 0,582.Nilai tersebut mendekati satu, artinyakemampuanvariasivariabel-

variabelindependenmenjelaskan variabel dependen cukup kuat. Hasil pengujian ini juga menunjukkan bahwa kemampuanvariasi variabel kualitas produk dan citra merek terhadap keputusan pembelian sebesar 58,2\% sedangkan $41,8 \%$ dijelaskan oleh variabel lain diluar model ini.

Analisis kolerasi berganda (R) digunakan untuk mengetahui tinggi rendah dan arah hubungan antara kualitas produk (X1), citra merek (X2) secara simultan dengan keputusan pembelian (Y). Besarnya koefesien korelasi ganda secara simultan dapat diketahui dari besarnya nlai $\mathrm{R}$ pada tabel 4,9 di atas. Nilai R-0.763 yang bernilai positif menunjukkan hubungan yang positif atau searah. Berdasarkan kriteria tinggi rendahnya hubungan manurut Sugiyono (2010) maka koefisien korelasi berganda (R) sebesar 0,763 di atas terletak di antara 0,6-08 yang berarti kolerasi kuat. Artinya adalah bahwa secara bersama-sama (simultan) terdapat hubungan positif yang kuat antara kualitas produk (X1), citra merek (X2) dengan keputusan pembelian (Y) pada Galeri Teknologi di Sempidi.

Berdasarkan hasil analisis data di atas lapat dijelaskan beberapa hal sebagai perikut:

Pengaruh kualitas produk terhadap keputusan pembelian

Berdasarkan hasil uji Statistik t ( $\mathrm{t}-$ test) diketahui nilai $\mathrm{t}$ hitung sebesar 7,528 dengan taraf signifikansi 0,000. Nilai $T$ hitung 7,528> $\mathrm{t}$ tabel 1,98 sehingga Ho ditolak. Maka dari itu dapat disimpulkan bahwa ada pengaruh positif kualitas produk terhadap keputusan pembelian.Hasil pengujian pengaruh koefisien regresi yang positif menunjukkan semakin tinggi kualitas produk maka semakin tinggi pula keputusan pembelian.

Peningkatan kualitas produk merupakan sebuah upaya yang bisa dilakukan oleh perusahaan agar dapat tetap memuaskan konsumen dan dapat menambah jumlah konsumen. Dalam perkembangan suatu perusahaan, persoalan kualitas produk akan ikut menentukan pesat tidaknnya perkembangan perusahaan tersebut. Maka dari itu Perusahaan harus selalu berusaha memuaskan konsumen mereka dengan menawarkan produk berkualitas sehingga berdampak kepada rasa puas di hati konsumen.Hal ini sesuai dengan yang dikemukakan oleh Kotler dan Armstrong (2010:87), yaitu kualitas produk (product quality) merupakan salah satu sarana positioning utama pemasar. Kualitas mempunyai dampak langsung pada kinerja produk atau jasa, oleh karena itu kualitas berhubungan erat dengan nilai dan kepuasan pelanggan

Ni Ketut Budiani

Ni Wayan Ari Sudiartini

A.A Elik Astari

I Dewa Nyoman Usadha 
Jurnal Satyagraha, Vol. 02, No. 02, Agustus 2019 - Januari 2020 ISSN :2620-6358

Hasil penelitian ini didukung oleh penelitian yang dilakukan oleh I Made Agus Suriadi, (2015) yang berjudul "Pengaruh Brand Image, Celebrity Endorser, Kualitas Produk, dan Harga Terhadap Keputusan Pembelian Sepeda Motor Matic Merek Honda di PT. Dwi Jati Motor Denpasar" yang menyimpulkan secara serenpak brand image, celebrity endorser, kualitas produk, dan harga berpengaruh positif dan signifikan terhadap keputusan pembelian sepeda motor matic Honda di PT. Dwi Jati Motor Denpasar. Diketahui juga berpengaruh positif dan signifikan secara parsial antara Brand Image, Celebrity Endorser, Kualitas Poduk, dan Harga Terhadap Keputusan Pembelian Sepeda Motor Matic Merek Honda di PT. Dwi Jati Motor Denpasar.

\section{Pengaruh citra merek terhadap keputusan pembelian}

Berdasarkan hasil uji Statistik t (ttest) diketahui nilai $t$ hitung sebesar 7,051 dengan taraf signifikansi 0,000. Nilai T hitung 7,051> t tabel 1,98 sehingga Ho ditolak. Maka dari itu dapat disimpulkan bahwa ada pengaruh positif citra merek terhadap keputusan pembelian.Hasil pengujian pengaruh koefisien regresi yang positif menunjukkan semakin tinggi citra merek maka semakin tinggi pula keputusan pembelian.

Brand yang kuat dapat mempengaruhi keputusan pembelian, maka dari itu perusahaan yang berhasil membangun brand yang kuat akan memiliki nilai tambah di mata konsumen. Keberhasilan sebuah perusahaan dalam menciptakan citra merek akan sangat berguna bagi para konsumen, karena pada akhirnya citra merek akan sangat mempengaruhi persepsi konsumen dan penilaian konsumen terhadap alternative merek yang dihadapinya. Hasil analisis koefisien regresi berganda diketahui bahwa citra merek memiliki nilai koefisien terbesar yaitu 0,327, maka dari itu dapat disimpulkan bahwa variabel yang paling mempengaruhi keputusan pembelian adalah citra merek.

Penelitian lain yang mendukung hasil penelitian yang menyatakan bahwa citra merek berpengaruh signifikan terhadap keputusan pembelian konsumen di lakukan oleh Alana, (2013) yang berjudul "Pengaruh Citra Merek, Desain, dan Fitur Produk Terhdap Keputusan Pembelian Handphone Nokia" (Studi Kasus pada Mahasiswa Universitas Diponegoro) yang menyimpulkan bahwa secara signifikan citra merek ternyata berpengaruh positif dan secara signifikan desain produk berpengaruh positif juga terhadap keputusan pembelian. Sedangkan secara bersama-sama, citra merek, desain, dan fitur produk berpengaruh positif terhadap keputusan pembelian.

\section{Kesimpulan}

Berdasarkan hasil analisis data dan pembahasan maka penulis dapat disimpulkan bahwa:

a. Hasil F-test memang benar ada pengaruh positif dan signifikan secara simultan antara kualitas produk dan brand image terhadap purchase intention pada galeri teknologi. Koefisien korelasi berganda menyatakan bahwa ada hubungan yang positif secara simultan antara kualitas produk dan brand image

Ni Wayan Ari Sudiartini

A.A Elik Astari

I Dewa Nyoman Usadha 
Jurnal Satyagraha, Vol. 02, No. 02, Agustus 2019 - Januari 2020 ISSN :2620-6358

dengan purchase intention konsumen. Koefisien determinasi diperoleh sebesar $58,2 \%$, berarti besarnya variasi hubungan antara kualitas produk dan brand image secara simultan terhadap purchase intention konsumen adalah $58,2 \%$.

b. Ada pengaruh yang signifikan secara parsial antara kualitas produk dan brand image terhadap purchase intention konsumen pada galeri teknologi.Hasil analisis karakteristik responden diperoleh bahwa jenis kelamin laki-laki lebih banyak $(55,6 \%)$ dibandingkan jumlah perempuan hanya $(44,4 \%)$, berdasarkan umur diperoleh responden umur 20-30 tahun sebanyak 40 orang $(44,4 \%)$, umur $31-40$ tahun sebanyak 35 orang $(38,9 \%)$, umur $>40$ tahun sebanyak 15 orang $(16,7 \%)$, dan berdasarkan tingkat pendidikam diperoleh tingkat pendidikan yang terbanyak adalah Diploma/PT sebanyak 80 orang $(88,9 \%)$.

Di dalam hal ini yang sangat memperhatikan kualitas produk dan brand image adalah laki-laki yang berumur 2030 tahun yang pendidikannya Diploma/PT.

c. Kualitas produk merupakan variabel dominan yg berpengaruh terhadap purchase intention konsumen pada galeri teknologi.

\section{Saran}

Berdasarkan hasil penelitian dan pembahasan tersebut diatas maka dapat penulis sarankan bagi manajemen perusahan sebagai berikut:
Pada variabel kualitas produk, nilai rata-rata item yang terkecil adalah smartphone samsung aman dan mudah dipakai oleh konsumen, oleh karena itu disarankan kepada produsen samsung agar menyediakan produk yang sesuai dengan umur pemakai, misalnya orang tua membutuhkan keypad dengan tombol yang besar.

\section{Daftar Pustaka}

Alana, Aditya Yessika., Hidayat, Wahyu., Handoyo, Joko W. 2013. Pengaruh CitraMerek, Desain, dan Fitur Produk terhadap Keputusan Pembelian

Handphone Nokia (Studi Kasus pad a Mahasiswa Universitas Diponegor o). Jurnal Ilmu Administrasi Bisnis, 2(2), hal.69-77

Ghozali,Imam.2001.Aplikasi Analisis Multivariate Dengan Program SPSS.Semarang :Badan Penerbit Universitas Diponogoro

Jantje Sepang dan Sjendry Loindong (2017 Vol.5).Pengaruh Kualitas Produk, Harga Dan Promosi Terhadap Keputusan Pembelian Mobil Nissan X-Trail Pada Pt. Wahana Wirawan Manado.Jurnal Riset Ekonomi, Manajemen, Akuntansi dan Bisnis

Kotler, Philip dan Amstrong, Gary, (2014), Principles of Marketin, 12th Edition, Jilid 1 Terjemahan Bob Sabran Jakarta : Erlangga

Kotler dan Keller. 2009.Manajemen

Pemasaran. Jilid I.Edisi 13 Jakarta: Erlangga.

Wahyuni, Dewi Urip. 2008. "Pengaruh Motivasi, Persepsi dan Sikap Konsumen Terhadap Keputusan Pembelian Sepeda 
Jurnal Satyagraha, Vol. 02, No. 02, Agustus 2019 - Januari 2020 ISSN :2620-6358

Motor Merek "Honda" di Kawasan Surabaya

Barat". Jurnal Ekonomi Manajemen. Hal. 30

- 37. STIE Fatahillah Surabaya. Surabaya

Ni Ketut Budiani

Ni Wayan Ari Sudiartini

A.A Elik Astari

I Dewa Nyoman Usadha 